\title{
KAJIAN EFEKTIFITAS DAN KONTRIBUSI PAJAK TERHADAP PAD KABUPATEN MINAHASA UTARA
}

\author{
Daysi S.M.Engka, Steeva Y.L.Tumangkeng \\ Ekonomi Pembangunan-Fakultas Ekonomi dan Bisnis \\ Universitas Sam Ratulangi
}

\begin{abstract}
ABSTRAK
Pajak daerah sebagai salah satu sumber PAD diharapkan mampu memberikan kontribusi terhadap PAD Kabupaten Minahasa Utara. Penelitian ini bertujuan untuk Mengetahui besar kontibusi pajak terhadap pendapatan asli daerah Kabupaten Minahasa Utara, Mengetahui tingkat efektifitas pajak daerah Kabupaten Minahasa Utara. Manfaat Penelitian Dapat menjadi bahan masukan bagi pemerintah daerah Kabupaten Minahasa Utara dalam mengatur dan mengelolah keuangan daerah. Dapat menjadi bahan publikasi bagi pihak - pihak yang membutuhkan informasi menyangkut pajak dan PAD Kabupaten Minahasa Utara. Dengan menggunakan alat analisis Efektifitas dan Kontribusi di pakai untuk mengetahui seberapa besar tingkat efektifitas pemungutan pajak di Kabupaten Minahasa Utara dan analisis kontribusi untuk melihat peranan Pajak terhadap PAD.Luaran yang akan di hasilkan dalam penelitian ini yaitu berupa kajian Publikasi Ilmiah yang akan di muat dalam Jurnal Terakreditasi Nasional.
\end{abstract}

\section{Kata Kunci : Pajak, PAD}

\begin{abstract}
As one of the local tax revenue sources are expected to contribute to PAD North Minahasa regency. This study aims to Know, contributing substantial tax on revenue North Minahasa Regency, Knowing the level of effectiveness of local tax North Minahasa regency. Benefits Research can be input for the regional government of North Minahasa Regency in organizing and managing the regional finance. May be the publicity material for the party - those who need the information concerning taxes and PAD North Minahasa Regency. By using analytical tools Effectiveness and Contributions in use to know how big the effectiveness of tax collection in North Minahasa Regency and contribution analysis to look at the role of Taxes on PAD.Luaran that will be generated in this study are in the form of a study of Scientific Publications that will fit in the Journal Accredited National.
\end{abstract}

Keywords : Taxes, PAD 


\section{PENDAHULUAN}

Pelaksanaan otonomi daerah yang menitikberatkan pada Daerah Kabupaten dan Daerah Kota dimulai dengan adanya penyerahan sejumlah kewenangan (urusan) dari Pemerintah Pusat ke Pemerintah Daerah yang bersangkutan.Penyerahan berbagai kewenangan dalam rangka desentralisasi ini memerlukan banyak faktor pendukung.Salah satu faktor pendukung yang secara signifikan menentukan keberhasilan pelaksanaan otonomi daerah adalah kemampuan daerah untuk membiayai pelaksanaan kekuasaan/kewenangan yang dimilikinya. PAD (Pendapatan Asli Daerah) merupakan sumber pembiayaan yang paling penting dimana komponen utamanya adalah penerimaan yang berasal dari komponen pajak daerah dan retribusi daerah. Pajak daerah berdasarkan UU No. 28 Tahun2009 adalah kontribusi wajib kepada daerah yang terutang oleh orang pribadi atau badan yang bersifat memaksa berdasarkan Undang-Undang dengan tidak mendapatkan imbalan secara langsung dan digunakan untuk keperluan daerah bagi sebesar-besarnya kemakmuran rakyat. Retribusi daerah atau retribusi UU No. 28 Tahun 2009 adalah pemungutan daerah sebagai pembayaran atau jasa atau pemberian izin tertentu yang khusus disediakan dan/atau diberikan oleh pemerintah daerah untuk kepentingan orang pribadi atau badan.

Menurut Undang-Undang Nomor 33 Tahun 2004 tentang Perimbangan Keuangan antar Pemerintah Pusat dan Pemerintah Daerah menyebutkan bahwa sumber-sumber pendapatan daerah adalah:

1. Pendapatan Asli Daerah (PAD);

2. Dana Perimbangan;

3. Lain-lain pendapatan daerah yang sah.

Pendapatan Asli Daerah (PAD) menurut Undang-Undang Nomor 33 Tahun 2004 adalah:

1. Pajak Daerah;

2. Retribusi Daerah;

3. Hasil pengelolaan kekayaan daerah yang dipisahkan; dan Lain-lain PAD yang sah.

Dalam upaya menciptakan kemandirian daerah, Pendapatan Asli Daerah (PAD) menjadi factor yang sangat penting dimana PAD akan menjadi sumber dana dari daerah sendiri. Namun demikian, realitas menunjukkan bahwa PAD hanya mampu membiayai belanja pemerintah daerah yang paling tinggi sebesar 20\% (Kuncoro 2007:2).Ketergantungan pemerintah daerah kepada pemerintah pusat masih cukup tinggi.

Pajak Daerah secara garis besar dibedakan menjadi 2 (dua), yaitu pajak daerah yang dipungut pemerintah daerah tingkat propinsi (Pajak Propinsi), berupa pajak kendaraan bermotor, bea balik nama kendaraan bermotor, pajak bahan bakar kendaraan bermotor, pajak air permukaan, pajak rokok, dan pajak daerah yang dipungut oleh pemerintah daerah tingkat Kabupaten/Kota, berupa pajak hotel, pajak restoran, pajak hiburan, pajak reklame, pajak penerangan jalan, pajak mineral bukan logam dan batuan, pajak parkir, pajak air tanah, pajak sarang burung walet, pajak bumi dan bangunan perdesaan dan perkotaan, dan BPHTB. Sedangkan, retribusi daerah menurut UU No. 28 Tahun 2009 yaitu jasa umum dan jasa usaha.

Dalam pengelolaan keuangan daerah, faktor kemampuan daerah merupakan hal yang penting, khususnya dalam era otonomi daerah.Kemampuan keuangan dan anggaran daerah pada dasarnya adalah kemampuan dari pemerintahan daerah dalam meningkatkan penerimaan pendapatan asli daerahnya. Disini akan lebih mengarah pada aspek kemandirian dalam bidang keuangan, biasanya diukur dengan desentralisasi fiskal atau otonomi fiskal daerah, yang dapat diketahui melalui 
perhitungan kontribusi Pendapatan Asli Daerah terhadap total APBD serta kontribusi pajak daerah dan retribusi daerah terhadap PAD ( Susetyo, 2008: 39-53).

Dalam mengestimasi potensi PAD, diperlukan informasi dan tolak ukur yang riil terjadi di lapangan dan secara konkrit dikehendaki oleh masyarakat di daerah. Salah satu tolak ukur finansial yang dapat digunakan untuk melihat kesiapan daerah dalam pelaksanaannya adalah dengan mengukur seberapa jauh kemampuan keuangan suatu daerah. Salah satunya adalah dengan mengoptimalkan hasil pajak daerah yang sudah ada. Pajak daerah sebagai salah satu sumber PAD diharapkan mampu memberikan kontribusi terhadap PAD.

Manado-Bitung yang merupakanPusat Kegiatan Nasional (PKN) yang terdiri darikecamatanKalawat,kecamatan Airmadidi, kecamatan Kauditan dan kecamatan Kema. Adanya $\mathrm{r}$ encana pembangunanJalanTol Manado-Bitung dan Pembangunan Jalur Kereta Api Pulau Sulawesi,memperkuat posisi strategis Kabupaten Minahasa Utara terhadap perkembangan ekonomidan rencana pengembangan metropolitan BIMINDO. Hal ini perlu dikelola secara baikagar dapat memberikan dampak positif bagi percepatan pembangunandi Kabupaten Minahasa Utara dengan tetap memperhatikan aspek pembangunan berkelanjutan.

Realitas menunjukan bahwa PAD hanya mampu membiayai belanja pemerintah daerah yang paling tinggi sebesar 20\% meunjukan bahwa Ketergantungan Pemerintah daerah kepada Pemerintah Pusat sangat besar.Seiring dengan semangat otonomi daerah di harapkan Pemerintah daerah bisa lebih kreatif menggali dan memanfaatkan potensi yang ada di daerah.Peningkatan PAD dari waktu ke waktu dalam rangka pembiayaan pembangunan di daerah merupakan ciri dari kemandirian suatu daerah. Akan tetapi apabila pemerintah terlalu menekankan pada perolehan PAD, maka masyarakat akan semakin terbebani dengan berbagai pajak dan retribusi dengan maksud "pencapaian target" (Widjaja 2005).Namun di satu sisi Pemerintah Daerah juga di haruskan untuk lebih bisa memanfaatkan dan menggali potensi - potensi PAD yang di dalamnya salah satu bersumber dari pajak dalam rangka pelaksanaan pembagunan di daerah.

Dalam rangka pemanfaatan potensi pajak untuk peningkatan PAD sehingga perlu adanya suatu kajian tentang besar kontribusi pajak terhadap PAD dan seberapa besar tingkat efektivitas pemungutan pajak yang ada di Kabupaten Minahasa Utara.

\section{Pendapatan Asli Daerah (PAD)}

Augustyas (2013) mengatakan Pandapatan Asli Daerah merupakan sumber pendapatan daerah yang berasal dari kegiatan ekonomi daerah itu sendiri. Pendapatan Asli Daerah (PAD) merupakan salah satu pilar kemandirian suatu daerah.

\section{Fungsi Pajak}

Menurut (Mardiasmo, 2011: 2) ada dua fungsi pajak, yaitu sebagai berikut.

1. Fungsi budgetair

Pajak sebagai sumber dana bagi pemerintah untuk membiayai pengeluaranpengeluarannya.

\section{Fungsi mengatur (regulerend)}

Pajak sebagai alat untuk mengatur dan melaksanakan kebijakan pemerintah dalam bidang sosial dan ekonomi. 


\section{Pembagian Pajak Menurut Golongan, Sifat, dan Pemungutannya}

Menurut (Waluyo, 2013: 12) pajak dapat dikelompokkan ke dalam tiga kelompok, yaitu sebagai berikut.

1. Menurut golongan atau pembebanan, dibagi menjadi berikut ini.

a. Pajak langsung, adalah pajak yang pembebanannya tidak dapat dilimpahkan pihak lain, tetapi harus menjadi beban langsung Wajib Pajak yang bersangkutan. Contoh: Pajak Penghasilan.

b. Pajak tidak langsung, adalah pajak yang pembebanannya dapat dilimpahkan kepada pihak lain. Contoh: Pajak Pertambahan Nilai

2. Menurut Sifat

Pembagian pajak menurut sifat dimaksudkan pembedaan dan pembagiannya berdasarkan ciriciri prinsip adalah sebagai berikut.

a. Pajak Subjektif, adalah pajak yang berpangkal atau berdasarkan pada subjeknya yang selanjutnya dicari syarat objektifnya, dalam arti memperhatikan keadaan dari Wajib Pajak. Contoh: Pajak Penghasilan

b. Pajak Objektif, adalah pajak yang berpangkal atau berdasarkan pada objeknya, tanpa memperhatikan keadaan dari Wajib Pajak. Contoh: Pajak Pertambahan Nilai dan Pajak Penjualan atas Barang Mewah

3. Menurut Pemungutan dan Pengelolanya, adalah sebagai berikut.

a. Pajak pusat, adalah pajak yang dipungut oleh pemerintah pusat dan digunakan untuk membiayai rumah tangga negara. Contoh: Pajak Penghasilan, Pajak Pertambahan Nilai, dan Pajak Penjualan atas Barang Mewah, Pajak Bumi dan Bangunan, dan Bea Materai

b. Pajak daerah, adalah pajak yang dipungut oleh pemerintah daerah dan digunakan untuk membiayai rumah tangga daerah. Contoh: Pajak Reklame, Pajak Hiburan, Bea Perolehan Hak atas Tanah dan Bangunan (BPHTB), Pajak Bumi dan Bangunan sektor perkotaan dan pedesaan.

\section{Sistem Pemungutan Pajak}

Menurut (Wirawan B. Ilyas \& Richard Burton, 2011: 30) sistem pemungutan pajak dapat dibagi menjadi empat macam, yaitu official assessment system, semiself assessment system, self assessment system, dan withholding system.

1. Official assessment system adalah sustu sistem pemungutan pajak yang memberi wewenang kepada pemungut pajak (fiskus) untuk menentukan besarnya pajak yang harus dibayar (pajak yang terutang) oleh seseorang. Dengan sistem ini masyarakat (WP) bersifat pasif dan menunggu dikeluarkan suatu ketetapan pajak oleh fiskus. Besarnya utang pajak seseorang baru diketahui setelah adanya surat ketetapan pajak.

2. Semiself assessment system adalah suatu sistem pemungutan pajak yang memberi wewenang pada fiskus dan WP untuk menentukan besarnya pajak seseorang yang terutang. Dalam sistem ini, setiap awal tahun pajak WP menentukan sendiri besarnya pajak yang terutang untuk tahun berjalan yang merupakan angsuran bagi WP yang harus disetor sendiri. Baru kemudian pada akhir tahun pajak fiskus menentukan besarnya utang pajak yang sesungguhnya berdasarkan data yang dilaporkan oleh WP.

3. Self assessment system adalah suatu sistem pemungutan pajak yang memberi wewenang penuh kepada WP untuk menghitung, memperhitungkan, menyetorkan, dan melaporkan sendiri besarnya utang pajak. Dalam sistem ini WP yang aktif sedangkan fiskus tidak turut 
campur dalam penentuan besarnya pajak yang terutang, kecuali WP melanggar ketentuan yang berlaku.

4. Withholding system adalah suatu sistem pemungutan pajak yang memberi wewenang pada pihak ketiga untuk memotong/memungut besarnya pajak yang terutang. Pihak ketiga yang telah ditentukan tersebut selanjutnya menyetor dan melaporkannya kepada fiskus. Pada sistem ini, fiskus dan WP tidak aktif. Fiskus hanya bertugas mengawasi saja pelaksanaan pemotongan/pemungutan yang dilakukan oleh pihak ketiga.

\section{Pengertian Pajak Daerah}

Menurut (Wirawan B. Ilyas \& Richard Burton, 2011: 28) pajak daerah adalah jenis pajak yang dipungut oleh pemerintah daerah yang dalam pelaksanaannya sehari-hari dilakukan oleh Dinas Pendapatan Daerah (Dispenda). Hasil dari pemungutan pajak daerah dikumpulkan dan dimasukkan sebagai bagian dari penerimaan Anggaran Pendapatan dan Belanja Daerah (APBD).

Dasar hukum pemungutan Pajak Daerah dan Retribusi Daerah adalah Undang-undang No. 28 Tahun 2009 tentang Pajak Daerah dan Retribusi Daerah. berikut.

Beberapa pengertian atau istilah yang terkait dengan Pajak Daerah antara lain sebagai

1. Daerah Otonom, selanjutnya disebut Daerah, adalah kesatuan masyarakat hukum yang mempunyai batas-batas wilayah yang berwenang mengatur dan mengurus urusan pemerintahan dan kepentingan masyarakat setempat menurut prakarsa sendiri berdasarkan aspirasi masyarakat dalam sistem Negara Kesatuan Republik Indonesia.

2. Pajak Daerah, yang selanjutnya disebut pajak, adalah kontribusi wajib kepada Daerah yang terutang oleh orang pribadi atau badan yang bersifat memaksa berdasarkan Undang-undang, dengan tidak mendapatkan imbalan secara langsung dan digunakan untuk keperluan Daerah bagi sebesar-besarnya kemakmuran rakyat.

3. Badan, adalah sekumpulan orang dan/atau modal yang merupakan kesatuan, baik yang melakukan usaha maupun yang tidak melakukan usaha yang meliputi perseroan terbatas, perseroan komanditer, perseroan lainnya, Badan Usaha Milik Negara (BUMN), atau Badan Usaha Milik Daerah (BUMD) dengan nama dan dalam bentuk apapun, firma, kongsi, koperasi, dana pensiun, persekutuan, perkumpulan, yayasan, organisasi massa, organisasi sosial politik, atau organisasi lainnya, lembaga dan bentuk badan lainnya termasuk kontrak investasi kolektif dan bentuk usaha tetap.

4. Subjek Pajak, adalah orang pribadi atau badan yang dapat dikenakan Pajak.

5. Wajib Pajak, adalah orang pribadi atau badan, meliputi pembayar pajak, pemotong pajak, dan pemungut pajak, yang mempunyai hak dan kewajiban perpajakan sesuai dengan ketentuan peraturan perundang-undangan perpajakan daerah.

Sesuai dengan pembagian administrasi daerah, maka pajak daerah dapat digolongkan menjadi2 macam yaitu sebagai berikut.

1. Pajak Daerah Tingkat I atau Pajak Propinsi, terdiri dari:

a. Pajak kendaraan bermotor dan kendaraan di atas air, yaitu pajak atas kepemilikan dan/atau penguasaaan kendaraan bermotor dan kendaraan di atas air.

b. Bea balik nama kendaraan bermotor dan kendaraan di atas air, yaitu pajak atas penyerahan hak milik kendaraan bermotor dan kendaraan di atas air sebagai akibat dari perjanjian dua pihak atau 
perbuatan sepihak atau keadaan yang terjadi karenajual beli, tukar menukar, hibah, warisan, atau pemasukan ke dalam badan usaha.

c. Pajak bahan bakar kendaraan bermotor, yaitu pajak atas bahan bakar yang disediakan atau dianggap digunakan untuk kendaran bermotor, termasuk bahan bakar yangdigunakan untuk kendaraan di atas air.

d. Pajak pengambilan dan pemanfaatan air bawah tanah dan air permukaan, yaitu pajak atas pengambilan dan pemanfaatan air di bawah tanah dan/atau air permukaan untuk digunakan bagi orang pribadi atau bada, kecuali untuk keperluan dasar rumah tanggadan pertanian rakyat.

\section{Pajak Daerah Tingkat II atau Pajak Kabupaten/Kota}

a) Pajak Hotel, yaitu pajak atas pelayanan Hotel. Hotel adalah bangunan yang khusus disediakan bagi orang-orang untuk dapat menginap atau istirahat, memperoleh pelayanan, dan atau fasilitas lain dengan dipungut bayaran termasuk bangunan lainnya yang menyatu, dikelola dan dimiliki pihak yang sama, kecuali untuk pertokoan dan perkantoran.

b) Pajak Restoran, yaitu pajak atas pelayanan restoran. Restoran adalah tempat menyantap makanan dan atau minuman yang disediakan dengan dipungut bayaran, tidak termasuk jasa boga atau catering.

c) Pajak Hiburan, yaitu pajak atas penyelenggaraan hiburan. Hiburan adalah semua jenis pertunjukkan, permainan, ketangkasan, dan atau keramaian dengan nama dan bentukapapun yang ditonton atau dinikmati oleh setiap orang dengan dipungut bayaran,tidak termasuk penggunaan fasilitas untuk berolah raga.

d) Pajak Reklame, yaitu pajak atas penyelenggaraan reklame. Reklame adalah benda, alat perbuatan, atau media yang menurut bentuk dan corak ragamnya untuk tujuankomersial, dipergunakan untuk memperkenalkan, menganjurkan atau memuji suatu barang, jasa atau orang, ataupun untuk mencari perhatian umum kepada suatu barang, jasa atau orang yang ditempatkan atau dapat dilihat, dibaca dan atau didengarkan dari suatu tempat umum kecuali yang diperlukan oleh pemerintah.

e) Pajak Penerangan Jalan, yaitupajak atas penggunaan tenaga listrik, dengan ketentuan bahwa diwilayah daerah tersebut tersedia penerangan jalan, yang rekeningnyadibayar oleh pemerintah daerah.

f) Pajak Pengambilan dan pengolahan bahan galian Golongan C, yaitu pajak atas kegiatan pengambilan bahan galian Golongan $\mathrm{C}$ sesuai dengan peraturan perundangundangan yang berlaku

g) Pajak Parkir, yaitu tempat parkir diluar badan jalan yang disediakan oleh orangpribadi atau badan, baik yang disediakan berkaitan dengan pokok usaha maupun yang disediakan sebagai suatu usaha, termasuk penyediaan tempat penitipan kendaran bermotor dan garasi kendaraan bermotor yang memungut bayaran.

\section{METODE PENELITIAN}

\section{Metode Analisis}

Metode analisis data yang digunakan dalam penelitian ini yaitu analisis kontribusi dan analisis Rasio untuk melihat tingkat efektifitas pemungutan pajak daerah dan retribusi daerah terhadap PAD . Analisis kontribusi dan Analisis Rasio yang akan digunakan di jelaskan sebagai berikut :

1. Analisis Kontribusi

Kontribusi per jenis pajak daerah terhadap Pendapatan Asli Daerah (PAD) 


\section{Realisasi per jenis pajak \\ $K P J P=\longrightarrow 100 \%$ \\ Realisasi PAD}

2. Rasio Efektifitas

Mengukur efektifitas per jenis pajak daerah

$$
E P J P=\frac{\text { Realisasi per jenis pajak }}{\text { Target per jenis pajak }} \times 100 \%
$$

Untuk menilai tingkat efektivitas masing-masing pos pajak daerah dapat terlihat pada tabel di bawah ini.

Tabel. 1

Tabel Interpretasi Nilai Efektivitas

\begin{tabular}{|l|l|}
\hline Presentase & Kriteria \\
\hline$>\mathbf{1 0 0 \%}$ & Sangat efektif \\
\hline $\mathbf{9 0 - 1 0 0 \%}$ & Efektif \\
\hline $\mathbf{8 0 - 9 0 \%}$ & Cukup efektif \\
\hline $\mathbf{6 0 - 8 0 \%}$ & Kurang efektif \\
\hline $\mathbf{5 6 0 \%}$ & Tidak efektif \\
\hline
\end{tabular}

Sumber:Kepmendagri No.690.900-327, Tahun 1996 (dalam Dwirandra:2008)

\section{HASIL PENELITIAN DAN PEMBAHASAN}

\section{Pajak Daerah Kabupaten Minahasa Utara}

Pajak Daerah Kabupaten Minahasa Utara dari tahun ke tahun mengalami peningkatan, ini membawa arti bahawa Pemerintah Kabupaten Minahasa Utara konsisten dengan upaya Pemerintah untuk menggali dan memanfaatkan potensi daerah melalui penerimaan dari sector pajak guna menopang Pendapatan asli Daerah. Data perkembangan pajak Daerah kabupaten Minahasa Utara dapat dilihat pada gambar di bawah ini. 


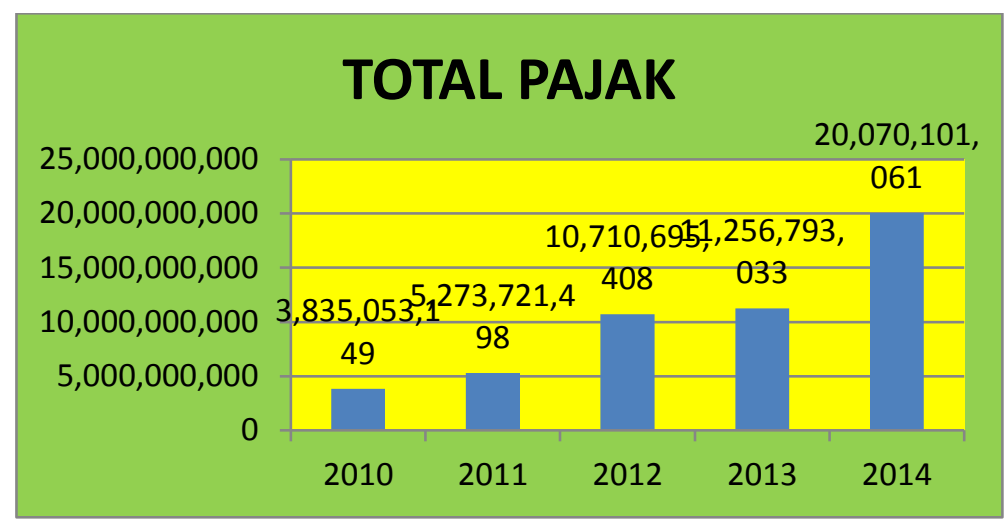

Gambar 1. Total Pajak Darah Kabupaten Minahas Utara Tahun 2010 - 2014

Dari gambar di atas dapat dilihat bahwa Pendapatan Asli Daerah yang berasal dari sector pajak terus mengalami kenaikan dari tahun ke tahun. Walaupun pada tahun 2012 ke tahun 2013 hanya terjadi peningkatan sedikit saja tetapi tahun 2014 terjadi peningkatan yang sangat signifikan.

Peningkatan Pendapatan Asli Daerah dari sector pajak dapat dilihat selengkapnya lewat perhhitungan efektivitas pajak setiap jenis pajak yang ada di Kabupaten Minahasa Utara. Berikut data efektivitas per jenis pajak di Kabupaten minahasa utara.

\section{Hasil Nilai Efektifitas Per Pajak Dan Kontribusinya} Efektifitas Dan Kontribusi Pajak Daerah Tahun 2015

Tabel .2

Efektifitas Dan Kontribusi Pajak Daerah Tahun 2015

\begin{tabular}{|l|c|c|c|c|}
\hline \multicolumn{1}{|c|}{ Jenis Pajak Daerah } & $\begin{array}{c}\text { Efektifita } \\
\mathbf{s ( \% )}\end{array}$ & Kriteria & $\begin{array}{c}\text { Kontrib } \\
\text { usi( } \%)\end{array}$ & Kriteria \\
\hline Pajak Hotel & 101,12 & Sangat Efektif & 6.72 & Sangat Kurang \\
\hline Pajak Restoran & 108,97 & Sangat Efektif & 16.03 & Kurang \\
\hline Pajak Hiburan & 100.16 & Sangat Efektif & 0.85 & Sangat Kurang \\
\hline Pajak Reklame & 118.15 & Sangat Efektif & 0.50 & Sangat Kurang \\
\hline Pajak Penerangan Jalan & 114.41 & Sangat Efektif & 27.17 & Sedang \\
\hline Pajak Mineral Bukan Logam Dan Batuan & 101.80 & Sangat Efektif & 4.02 & Sangat Kurang \\
\hline Pajak Air Tanah & 137.36 & Sangat Efektif & 7.20 & Sangat Kurang \\
\hline Pajak Sarang Burung Walet & 84.46 & Cukup Efektif & 0.10 & Sangat Kurang \\
\hline PBB & 100.85 & Sangat Efektif & 19.36 & Kurang \\
\hline BPHTB & 113.85 & Sangat Efektif & 18.02 & Kurang \\
\hline
\end{tabular}

Sumber data: Data diolah di Excel (2016)

\section{PAD, Total Pajak, dan Kontribusi Pajak Terhadap PAD}

Berdasarkan data - data yan sudah disajikan terlebih dahulu tentang efektivitas per jenis pajak dan efektivitas pajak setiap tahunnya, serta besarnya kontribusi per jenis pajak terhadap total pajak daerah, di bawah ini akan di sajikan data- data besarnya kontribusi pajak terhadap PAD kabupaten Minahasa Utara. 


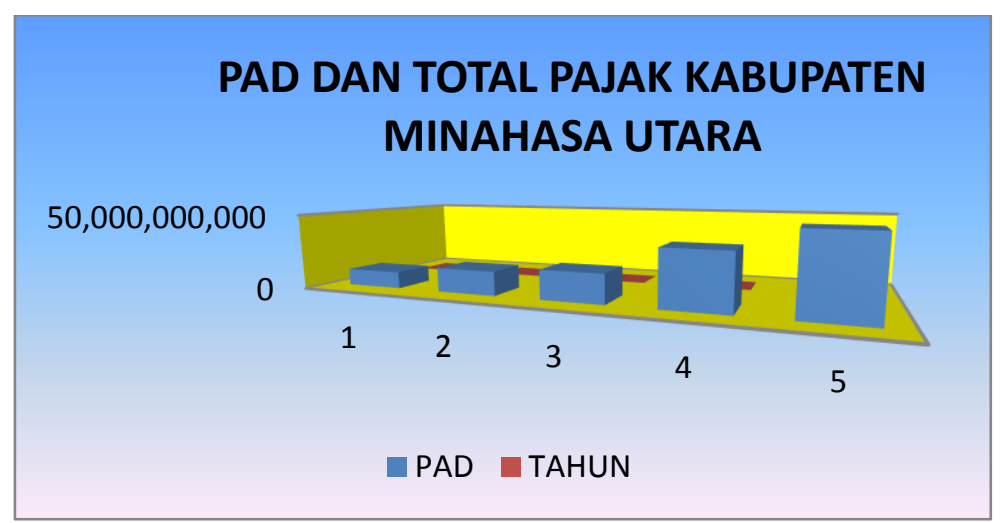

Gambar. 2 PAD Dan Total Pajak Daerah

Berdasarkan gambar perkembangan PAD, dan Total Pajak dapat dilihat bahwa dari tahun 2010 sampai tahun 2014 PAD dan Total Pajak daerah terus mengalami peningkatan dari tahun ke tahun . Selanjutnya berdasarkan data ini di hitung besarnya kontribusi pajak Daerah terhadap PAD Kabupaten Minahasa Utara yang disajikan pada gambar di bawah ini yaitu kontribusi pajak terhadap PAD sebagai berikut.

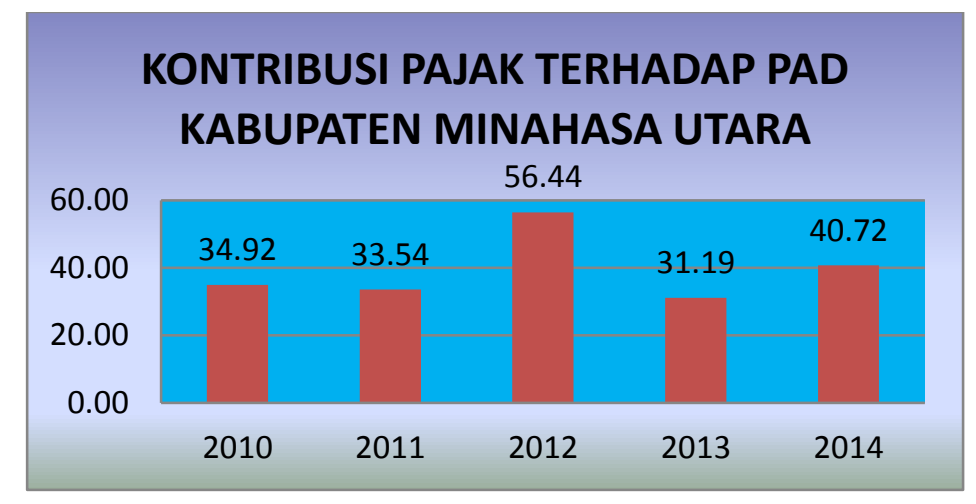

Gambar. 3 Kontribusi Pajak Terhadap PAD

Kabupaten Minahasa Utara Tahun 2010 - 2014

Berdasarkan data pada gambar diatas dapat dilihat bahwa kontribusi pajak daerah terhadap PAD paling besar yakni pada tahun 2012 dengan besar kontribusi yaitu 56,44 \%, kemudian diikuti tahun 2014 dengan kontribusi sebesar 40,72\%, dan paling kecil di tahun 2013 dengan besar kontribusi pajak terhadap PAD sebesar $31,19 \%$.

\section{KESIMPULAN DAN SARAN}

\section{Kesimpulan}

1. Perkembangan Pajak Daerah Kabupaten Minahasa utara dalam kurun waktu tahun 2010 sampai tahun 2014 menunjukan adanya peningkatan dari tahun ke tahun. 
2. Perkembangan pendapatan asli daerah (PAD) Kabupaten Minahasa utara dalam kurun waktu tahun 2010 sampai tahun 2014 menunjukan adanya peningkatan dari tahun ke tahun.

3. Tingkat Efektifitas pada tahun 2011 mengalami peningkatan pajak daerah terdapat pada pajak restoran dan pada tahun 2012-2014 mengalami peningkatan pajak daerah terdapat pada pajak BPHTB .Pada tahun 2015 mengalami peningkatan pajak daerah terdapat pada pajak air tanah.

4. Pajak BPHTB di Kabupaten Minahasa Utara dari tahun 2012-2014 selalu mengalami peningkatan dibandingkan dengan pajak-pajak yang lainnya.

\section{Saran}

Berdasarkan kesimpulan diatas maka ada beberapa saran yang terkaitan dengan penelitian, sebagai berikut :

1. Pemerintah Kabupaten Minahasa Utara harus lebih berusaha untuk dapat meningkatkan Peningkatan dalam mengelola Pendapatan Asli Daerah (PAD) sehingga Penerimaan Pajak Daerah bisa berperan dalam membiayai pelaksanaan pemerintahan yang ada di daerahnya dalam hal Belanja Daerah.

2. Pemerintah Kabupaten Minahasa Utara harus lebih berusaha perlu memperhatikan tingkat efektifitas Pajak daerah dan Belanja Daerah serta kontribusinya agar kedepannya tidak akan mengalami dan terjadi penurunan terhadap tingkat efektifitas Pajak Daerah dan Belanja Daerah serta kontribusinya.

3. Bagi peneliti selanjutnya untuk dapat meningkatkan penelitian yang berhubungan dengan analisis penerimaan pajak daerah serta pengaruhnya terhadap belanja daerah.

\section{DAFTAR PUSTAKA}

Abdul Halim, 2008. Akuntansi Sektor Publik Keuangan Daerah. Salemba Empat Jakarta. Agustine Yvone Kristaung. R. 2013. Metodologi Penelitian Bisnis \& Akuntansi. Penerbit Dian Rakyat Jakarta.

Ilyas \& Bruton, 2011. Hukum Pajak . Penerbit Salemba Empat Jakarta.

Mardiasmo, 2008. Perpajakan Edisi XV Revisi 2008. Penerbit Andi Yogyakarta. Mardiasmo, 2009. Perpajakan Edisi XVI Revisi 2009. Penerbit Andi Yogyakarta, Lasut, Pamela. 2014. Penelitian tentang Analisis Efektifitas Penerimaan Pajak Pengambilan dan Pengelolaan Mineral Bukan Logam dan Bantuan sebagai Sumber Pendapatan Asli Daerah Kota Tomohon . Universita Sam Ratulangi. Manado.

Resmi, Siti, 2007. Perpajakan Teori Kasus. Edisi ke IV, Salemba Empat, Jakarta. Supramono, Dan Damayanti T.W, 2010. Perpajakan Indonesia Mekanisme \& Perhitungan. Andi Yogyakarta. 
Siahaan, Marikot, 2013. Pajak Daerah \& Restribusi Daerah. Raja Grafindo Persada Jakarta.

Sambuaga, Dewi. 2011. Penelitian tentang Analisa Efektifitas pemungutan Pajak Bahan galian Golongan C Melalui Sistem Ketetapan Pajak Serta Kontribusinya Terhadap Pendapatan Asli Daerah Kota Manado. Universitas Sam Ratulangi. Manado.

Widarta, 2001. Mudah memahami otonomi Daerah. Jakarta Pustaka Utama.

Waluyo, 2013. Perpajakan Indonesia Edisi kesebelas. Salemba Empat. Jakarta.

Undang- Undang N0. 28 Tahun 2009 tentang Pajak Daerah \& Restribusi Daerah.

Undang-Undang No. 33 Tahun 2004 tentang pertimbangan Keuangan antara pemerintah pusat dan Daerah.

Undang-Undang No. 32 Tahun 2004 Tentang Pemerintahan Daerah. 